\title{
Load Vehicle Damage Factor (LVDF) on National Highways in the Colombian Caribbean Region
}

\author{
Fernando Jove Wilches*, Jhon Jairo Feria Díaz and Rodrigo Hernandez Ávila \\ Department of Civil Engineering, University of Sucre, Cra. 28 \#5-267, Puerta Roja, Sincelejo, Colombia; \\ fejowi@yahoo.es, jhon.feria@unisucre.edu.co,rodrigo.hernandez@unisucre.edu.co
}

\begin{abstract}
Objective: To determine damage factors of trucks that most frequently use national roads in the Colombian Caribbean Region. Methods/Analysis: Information provided by the National Institute of Colombian Roads was used according to a mobile weighing operation carried out in 2005. Damage factors for each truck type were obtained from the weights of each vehicular axle, by implementing three different methods: The AASHTO general method, AASHTO simplified method and SHELL method. Findings: 16,611 heavy trucks were totally analyzed in the operation. Subsequently, results obtained were compared with those observed in other similar studies carried out in the country. Application: Damage factors defined in this study for lighter vehicles have lower values than those observed in previous measurements. In contrast, for the case of heavier trucks, the opposite occurs.
\end{abstract}

Keywords: Cargo, Damage factors, Roads, Vehicles

\section{Introduction}

Vehicle traffic on roads is one of the most critical input parameters for pavement design, traditionally associated as the element of the greatest uncertainty 1 . Therefore, great care must be taken when estimating traffic loads to which a structure will be subject during service life. The greater the existing lags between estimated and actual traffic, the greater the economic damage generated by cost overruns, due to demand overestimation or vehicular traffic underestimation. Both situations would cause pavement premature deterioration and increase operating costs for road users. Adequate determination of traffic loads is vitally important for road design, since it reduces possible uncertainty this factor causes in determining expected performance in pavement structure.

Some road agencies, such as the American Association of State Highway and Transportation Officials (AASHTO), promote the use of vehicle load spectra as a tool for characterizing traffic for pavement design purposes 2,3 . Nonetheless, traffic characterization in terms of number of equivalent repetitions in the design lane remains equally valid, as it has traditionally been carried out in many countries.

In the Colombian case, although studies have been carried out at the national level regarding obtaining damage factors from commercial vehicles, at the Caribbean Region level this activity has not been as prolific. For this

${ }^{*}$ Author for correspondence 
reason, it is important to have private studies of this type to be able to establish design parameters adjusted to traffic conditions of the Regional Road Network.

Determining the number of equivalent simple axles of 8.2 tons in the design lane, is the technique most used by most pavement design methods for traffic characterization ${ }^{4}$, and it is basically based on expressing all the axles diversity that would make use of a track, in a certain number of reference standard axles that would cause a certain effect on the pavement $\frac{5,6}{}$. For conversion of mixed traffic to equivalent axles, basically two paths can be followed: through determination of the characteristic truck factor of the road corridor, or through the damage factors previously carried out and established by global studies, considered representative of the particular traffic conditions of the road under study ${ }^{7,8}$.

\subsection{Damage Factors for Commercial Vehicles}

"Damage factor" of a commercial vehicle is a value expressing the number of simple double-rim axles of 8.2 tons equivalent to the pass of that vehicle ${ }^{7}$. Thus, if for a given region the damage factors representative of the distinct types of commercial vehicles are known, it will be possible to "convert" all the mixed traffic, into equivalent standard axles, with data of a sector vehicular capacity properly differentiated in its different components.

To calculate the damage factor of each commercial vehicle, the sum of the equivalences of each of the axles that make up the vehicle ${ }^{7}$ is established, as expressed below:

$$
C V D F=\sum_{i=1}^{m} L E F
$$

Where: M: number of axles of the vehicle configuration

LEF: axle load equivalency factor

CVDF: commercial vehicle damage factor

There are several methods for the calculation of axle Load Equivalency Factors (LEF). However, for this study, the following will be taken into consideration:
- AASHTO General Method

- AASHTO Simplified Method

- SHELL method

\subsection{AASHTO General Method}

For the case of flexible pavements, the following regression equation based on the results of the AASHTO ${ }^{9}$ road test can be used:

$\log \left(\frac{W t x}{w t 18}\right)=4.79 \log (18+1)-4.79 \log (L x+L 2)+4.33 \log (L 2)+\frac{G t}{\beta x}-\frac{G t}{\beta 18}$

Eq 2.

Where:

Wtx:number of load applications of $\mathrm{x}$ magnitude per axis at time $t$.

Wt18:number of load applications of 18-kilopound magnitude in a time $t$.

Lx:magnitude of load per axle in kilopound.

L2:load code per axle, as this:

$\mathrm{L} 2=1$, for simple axle

$\mathrm{L} 2=2$, for tandem axle

$\mathrm{L} 2=3$, for tridem axle

$$
\begin{aligned}
& G t=\log \left[\frac{4.2-P t}{4.2-1.5}\right] \\
& \beta x=0.40+\frac{0.081(L x+L 2)^{3.23}}{(S N+1)^{5.19} L 2^{3.23}}
\end{aligned}
$$

$\beta 18$ :value of $\beta x$ when $L x$ is equal to 18 kilopounds and L2 is equal to 1

Pt: final serviceability index

$\mathrm{SN}$ :structural number as a function of thicknesses (in inches), modules of each layer and drainage conditions of the base and subbase, determined as follows:

$$
S N=a 1 \times h 1+a 2 \times h 2 \times m 2+a 3 \times h 3 \times m 3
$$

E 5.

a1: structural coefficient of the tread layer

a2: structural coefficient of the base layer 
a3: structural coefficient of the subbase layer

$\mathrm{m} 2$ : drainage coefficient of the base layer

m3: drainage coefficient of the subbase layer

$$
L E F=\frac{W t 18}{W t x}
$$

LEF: axle load equivalency factor

$\mathrm{LEF}=\mathrm{Wt} 18$

The practical difficulty of this method consists in the determination of the exact value of the structural number of each road where the weighing operations are carried out. For this study, a SN value of four was assumed, characteristic of pavement structures with typical thicknesses found in the country $\underline{10}$.

\subsection{Simplified AASHTO Method}

From the AASHTO road test it could be established that the impact of each load per individual axle in flexible pavements can be approximately estimated according to "the law of the fourth power" the damage caused to the pavement due to vehicular traffic increases exponentially with the increase in load per axle. This relationship is denoted by load equivalence fac$\operatorname{tor}^{9-12}$.

$$
L E F=\left(\frac{W 1}{W_{O}}\right)^{4}
$$

Where:

LEF:axle Load Equivalency Factor for flexible pavements

W1:load which equivalence with the standard is to be determined

WO: standard load

Depending on type of axle, the standard reference loads take the following values $\frac{10}{}$ :

$\mathrm{WO}=6.6$, for single axle simple wheel

$\mathrm{WO}=8.2$, for single axle double wheel

$\mathrm{WO}=15$, for tandem axle

$\mathrm{WO}=23$, for tridem axle

\subsection{SHELL Method}

SHELL recommends in its 1978 design method to use the following expression to calculate equivalent traffic for each type of axis ${ }^{10}$ :

$$
N e=2.4 \times 10^{-8} \times L^{4} \quad \text { Eq } 8 .
$$

Where:

Ne:Equivalence factor to simple double wheel axle of 8.2 tons

$\mathrm{L}=\mathrm{P}$, for double wheel single axle

$\mathrm{L}=\mathrm{P} / 2$, for tandem axle

$\mathrm{L}=\mathrm{P} / 3$, for tridem axle

$\mathrm{W}$ : load per axle in kilonewton

\section{Materials and Methods}

In this study, results obtained from damage factors coming from a weighing operation carried out in June 2005 on the Río Ariguaní - Ye de Ciénaga ${ }^{1}$ highway were analyzed. The Technical Support Sub-direction of the National Institute of Colombian Roads provided database of these operations.

\subsection{Types of Analyzed Vehicles}

The types of commercial vehicles listed in Table 1 were considered, corresponding to the most representative trucks using the national road network.

Sample Size

16,611 heavy trucks were totally analyzed in the operation, as detailed in Table 2.

\section{Results and Discussion}

The following are the most notable results achieved in the present study

\subsection{List of Unloaded and Loaded Vehicles}

The list of commercial vehicles analyzed under loading and unloaded conditions is presented In Table 3.

As Table 3 shows, most of the samples show loaded conditions. Out of the 16,611 vehicles analyzed, 15,786 
Table 1. Analyzed vehicles in the Study

\begin{tabular}{|c|c|c|}
\hline Vehicle Type & Code & DESCRIPTION \\
\hline Small two-axles truck & 08 & C2-P \\
\hline Large two-axle truck & 09 & C2-G \\
\hline Rigid three axle truck & 10 & C3 \\
\hline Truck with semi-trailer & 11 & C2-S1 \\
\hline Rigid 4 axle truck & 12 & C4 \\
\hline C3 truck with 1 axle in the semi-trailer & 13 & C3-S1 \\
\hline C2 truck with 2 axles in the semi-trailer & 14 & C2-S2 \\
\hline 5 axle trucks & 15 & C3-S2 \\
\hline 6-axle truck & 16 & C3-S3 \\
\hline
\end{tabular}

Table 2. Size of the analyzed sample

\begin{tabular}{|c|c|c|c|}
\hline \multicolumn{2}{|c|}{ TYPE OF VEHICLE } & \multirow{2}{*}{ NUMBER } & PERCENTAGE \\
\cline { 1 - 2 } CODE & DESCRIPTION & 638 & 3.8 \\
\hline 08 & C2-P & 3,202 & 19.3 \\
\hline 09 & C2-G & 582 & 3.5 \\
\hline 10 & C3 & 80 & 0.5 \\
\hline 11 & C2-S1 & 12 & 0.1 \\
\hline 12 & C4 & 21 & 0.1 \\
\hline 13 & C3-S1 & 160 & 1.0 \\
\hline 14 & C2-S2 & 2,166 & 13.0 \\
\hline 16 & C3-S2 & 9,750 & 58.7 \\
\hline
\end{tabular}

correspond to loaded trucks and 825 to unloaded trucks, representing $95.03 \%$ and $4.97 \%$ of the total sample respectively.

\subsection{Damage Factors Obtained}

Table 4 shows the damage factors obtained for loaded and unloaded trucks. These results have been obtained from 
Table 3. List of Loaded and Unloaded Vehicles

\begin{tabular}{|c|c|c|c|c|}
\hline \multicolumn{2}{|c|}{ TYPE OF VEHICLE } & \multicolumn{3}{c|}{ NUMBER OF TRUCKS } \\
\hline CODE & DESCRIPTION & UNLOADED & LOADED & ALL \\
\hline 08 & C2-P & 47 & 591 & 638 \\
\hline 09 & C2-G & 17 & 3,185 & 3,202 \\
\hline 10 & C3 & 22 & 560 & 582 \\
\hline 11 & C2-S1 & 10 & 70 & 80 \\
\hline 12 & C4 & 0 & 12 & 12 \\
\hline 13 & C3-S1 & 7 & 14 & 21 \\
\hline 14 & C2-S2 & 15 & 145 & 2,166 \\
\hline 15 & C3-S2 & 216 & 1,950 & 9,750 \\
\hline 16 & C3-S3 & 491 & 9,259 & 16,611 \\
\hline \multirow{2}{*}{ TOTALS } & No. & 825 & 15,786 & 100.00 \\
\cline { 2 - 5 } & \% & 4.97 & 95.03 & \\
\hline
\end{tabular}

Table 4. Damage factor for load and empty trucks

\begin{tabular}{|c|c|c|c|c|c|c|}
\hline \multirow{4}{*}{$\begin{array}{l}\text { TYPES OF } \\
\text { VEHICLE } \\
\text { Description }\end{array}$} & \multicolumn{6}{|c|}{ DAMAGE FACTORS } \\
\hline & \multicolumn{3}{|c|}{ LOADED TRUCKS } & \multicolumn{3}{|c|}{ UNLOADED TRUCKS } \\
\hline & \multicolumn{2}{|c|}{ AASHTO METHOD } & \multirow{2}{*}{$\begin{array}{c}\text { SHELL } \\
\text { METHOD }\end{array}$} & \multicolumn{2}{|c|}{ AASHTO METHOD } & \multirow{2}{*}{$\begin{array}{c}\text { SHELL } \\
\text { METHOD }\end{array}$} \\
\hline & General & Simplified & & General & Simplificado & \\
\hline $\mathrm{C} 2-\mathrm{P}$ & 0.12 & 0.13 & 0.12 & 0.009 & 0.013 & 0.009 \\
\hline $\mathrm{C} 2-\mathrm{G}$ & 2.49 & 2.77 & 2.93 & 0.065 & 0.082 & 0.066 \\
\hline $\mathrm{C} 3$ & 2.91 & 3.49 & 2.49 & 0.180 & 0.206 & 0.103 \\
\hline $\mathrm{C} 2-\mathrm{S} 1$ & 5.21 & 5.69 & 6.14 & 0.113 & 0.131 & 0.115 \\
\hline $\mathrm{C} 4$ & 5.49 & 6.63 & 4.64 & ---- & --- & --- \\
\hline $\mathrm{C} 3-\mathrm{S} 1$ & 2.71 & 3.11 & 3.08 & 0.113 & 0.154 & 0.110 \\
\hline $\mathrm{C} 2-\mathrm{S} 2$ & 2.92 & 3.18 & 3.23 & 0.208 & 0.250 & 0.207 \\
\hline C3-S2 & 4.54 & 5.14 & 3.82 & 0.146 & 0.245 & 0.130 \\
\hline C3-S3 & 5.61 & 5.93 & 4.51 & 0.147 & 0.256 & 0.133 \\
\hline
\end{tabular}


the Load Equivalence Factors (LEF) evaluated by the three considered methods. That of loaded vehicles was taken as a representative condition, because they represent $95 \%$ of the total sample.

Table 5 shows results of the analysis of variance and Tukey test to establish a comparison among the damage factors obtained for each type of vehicle under loaded condition.

According to the ANOVA results presented in Table 5 , it can be established that the damage factor for trucks C2-P, C2-S1, C4, C3-S1 and C2-S2, shows in each case, values significantly similar for the three methods. On the other hand, for the C2-G, C3, C3-S2 and C3-S3 trucks, damage factors obtained by the three methods are significantly different. From the ANOVA results, it can be established that damage factors obtained by the SHELL method, in most cases in which there is a significant difference, tend to present values lower than those from the general and simplified AASHTO methods. Out of the three methods applied, those presenting greater similarity in results, are the two from the AASHTO methods.
Due to the similarity between values obtained by the two AASHTO methods, and, considering that for the general method it is required to know the pavement Structural Number (SN), a parameter not always available, the damage factors obtained from the simplified AASHTO method are recommended to implement.

\subsection{Comparison of Damage Factors from Different Studies}

For comparative purposes, Table 6 shows damage factors under loaded conditions for the seven truck types of greater frequency established in Table 2, corresponding to this study and two other studies conducted at the national level. Values of column "1984" correspond to results obtained in the first phase of the National Pavement Research in Colombia. Values of column "1996", to those obtained by the Cauca University in a research carried out the same year and values of the "study" column correspond to those obtained in the present work, with the AASHTO simplified method.

Table 5. Hypothesis test for damage factors of load trucks

\begin{tabular}{|c|c|c|c|c|c|c|}
\hline \multirow{2}{*}{\begin{tabular}{c}
\multirow{2}{*}{ TYPES OF } \\
\cline { 2 - 6 }
\end{tabular}} & \multicolumn{2}{|c|}{ CALCULATION METHODS } & \multicolumn{2}{c|}{ HYPOTHESIS TESTS } \\
\cline { 2 - 7 } & GENERAL & SIMPLIFIED & SHELL & $\begin{array}{c}\text { STATISTICAL } \\
\text { Fo }\end{array}$ & $\begin{array}{c}\text { P } \\
\text { VALUE }\end{array}$ & $\begin{array}{c}\text { TUKEY } \\
\text { T0.05 }\end{array}$ \\
\hline \multirow{2}{*}{ C2-P } & 0.12 & 0.13 & 0.12 & 1.567 & $2.09 \mathrm{E}^{-01}$ & 0.02 \\
\hline C2-G & 2.49 & 2.77 & 2.93 & 29.669 & $1.4 \mathrm{E}^{-13}$ & 0.13 \\
\hline C3 & 2.91 & 3.49 & 2.49 & 51.718 & $1.6 \mathrm{E}^{-22}$ & 0.23 \\
\hline C2-S1 & 5.21 & 5.69 & 6.14 & 1.284 & 0.28 & 1.37 \\
\hline C4 & 5.49 & 6.63 & 4.64 & 0.745 & 0.48 & 4.01 \\
\hline C3-S1 & 2.71 & 3.11 & 3.08 & 0.131 & 0.878 & 2.13 \\
\hline C2-S2 & 2.92 & 3.18 & 3.23 & 0.548 & 0.579 & 0.76 \\
\hline C3-S2 & 4.54 & 5.14 & 3.82 & 89.867 & $3.62 \mathrm{E}^{-39}$ & 0.23 \\
\hline C3-S3 & 5.61 & 5.93 & 4.51 & $2,197.6$ & $0.0 \mathrm{E}^{+00}$ & 0.05 \\
\hline
\end{tabular}


Table 6. Comparison of damage factors from different studies

\begin{tabular}{|c|c|c|c|c|}
\hline \multicolumn{2}{|c|}{ TYPE OF VEHICLE } & \multicolumn{2}{c|}{ LOADED TRUCK DAMAGE FACTORS } \\
\hline CODE & DESCRIPTION & $\mathbf{1 9 8 4}$ & $\mathbf{1 9 9 6}$ & STUDY \\
\hline 08 & C2-P & 0.10 & 1.14 & 0.13 \\
\hline 09 & C2-G & 2.80 & 3.44 & 2.77 \\
\hline 10 & C3 & 4.60 & 3.76 & 3.49 \\
\hline 11 & C2-S1 & 1.40 & 3.37 & 5.69 \\
\hline 14 & C2-S2 & 6.70 & 3.42 & 3.18 \\
\hline 15 & C3-S2 & 5.30 & 4.40 & 5.14 \\
\hline 16 & C3-S3 & 5.90 & 4.72 & 5.93 \\
\hline
\end{tabular}

In this study, C2-P trucks have a slightly higher damage factor than in 1984, but significantly lower than in 1996. This may be because in recent years use of smaller trucks with lower capacity for cargo transportation has increased, which were taken as commercial vehicles since the rear axle corresponds to a single axle with double rim at the ends.

C2-G trucks in this study had a damage factor as in 1984, but significantly lower than in 1996. This trend may be related to the fact that to transport substantial amounts of cargo products represented by numerous units, it is more profitable to do so by using trucks of greater capacity (articulated type), where the operating costs per ton of cargo tend to be lower, being this more profitable for transporters.

C3 trucks have a decreasing damage factor. This can be explained because operating costs per ton transported to full capacity, tend to be higher than those presented in articulated trucks of greater capacity.

C2-S1 trucks have an increasing damage factor. However, in this case, this gradual increase in damage factor has minor impact on the deterioration generated in the pavements, as its pass frequency is among the lowest observed in the national road network.
C2-S2 trucks, in this study have a damage factor as in 1996, but significantly lower than in 1984. In this case, no meaningful change in damage factor associated with this kind of truck has occurred in recent years.

Trucks C3-S2 and C3-S3 in this study have a damage factor somewhat lower or similar as in 1984, as but significantly higher than in 1996. This can be attributed to the fact that a key component of the truck traffic of this type (about 21.3\% for C3-S2 trucks and 56.4\% for C3-S3 trucks, respectively) transport coal, with loads very close and even higher to the legal maximum allowed for this type of vehicles.

Table 7 shows the ANOVA results to establish comparison between damage factors determined in the present study and those obtained in 1984 and 1996.

Table 7 shows that in 1984, for vehicles type C2-G and C3-S3, there was no significant difference in damage factors obtained. In contrast, for vehicles C2-P, C3, C2-S1, C2-S2 and C3-S2, there are statistically significant differences in damage factors. In 1996, only in the C2-S2 vehicle the null hypothesis was not rejected, that is, no statistically significant differences were observed in the damage factor obtained. Whereas, for the rest of the vehicles compared, the null hypothesis is rejected, that is, 
Table 7. Hypothesis test for comparing damage factors from other studies

\begin{tabular}{|c|c|c|c|c|c|c|}
\hline \multirow{2}{*}{$\begin{array}{c}\text { TYPES OF } \\
\text { VEHICLES } \\
\text { DESCRIPTION }\end{array}$} & \multicolumn{3}{|c|}{ DAMAGE FACTORS FROM 1984} & \multicolumn{3}{|c|}{ DAMAGE FACTORS FROM 1996} \\
\hline & to & $\mathrm{t} \alpha / 2, \mathrm{n}-1$ & $\begin{array}{c}\text { DECISION } \\
\text { ON H }_{0}\end{array}$ & to & $\mathrm{t} \alpha / 2, \mathrm{n}-1$ & $\begin{array}{c}\text { DECISION } \\
\text { ON H }_{0}\end{array}$ \\
\hline $\mathrm{C} 2-\mathrm{P}$ & 5.22 & 1.96 & Rejected & 169.85 & 1.96 & Rejected \\
\hline C2-G & 0.71 & 1.96 & Not rejected & 16.47 & 1.96 & Rejected \\
\hline $\mathrm{C} 3$ & 13.98 & 1.96 & Rejected & 3.43 & 1.96 & Rejected \\
\hline $\mathrm{C} 2-\mathrm{S} 1$ & 10.35 & 2.00 & Rejected & 5.60 & 2.00 & Rejected \\
\hline $\mathrm{C} 2-\mathrm{S} 2$ & 15.24 & 1.96 & Rejected & 1.06 & 1.96 & Not rejected \\
\hline C3-S2 & 2.08 & 1.96 & Rejected & 9.40 & 1.96 & Rejected \\
\hline C3-S3 & 1.65 & 1.96 & Not rejected & 68.33 & 1.96 & Rejected \\
\hline
\end{tabular}

there was a significant difference in the damage factors obtained.

\section{Conclusion}

According to the study results, vehicles with greater load capacity tend to present the highest damage factors. This means that each time a heavy truck passes; it will generate more damage on the pavement than one of smaller capacity. Nonetheless, it must also be considered that larger trucks, having more capacity, can transport more load each time they make a repetition on the pavement. Damage factors of the lighter vehicles (rigid units) found in this study, have lower values than those observed in 1996. However, for heavier trucks (articulated units), the opposite occurs. This can be because transporters are taking full advantage of the capacity of larger trucks to reduce transportation costs per ton.

Because the damage factors for loaded trucks are significantly greater than those observed when not loaded and considering that more than $95 \%$ of trucks analyzed in the present study are loaded, it is recommended to con- sider this condition for the evaluation of traffic, unless there is information available regarding distribution of loaded and unloaded trucks.

\section{References}

1. Jove F. Espectros de carga y factores da-o de vehículos de carga en carreteras de la región Caribe colombiana. 1st ed. Barranquilla, Colombia: Universidad del Norte; 2011.

2. Prozzi JA, Hong F. Optimum statistical characterization of axle load spectra based on load associated. International Journal of Pavement Engineering. 2009; 8(4):323-30. Crossref.

3. American Association of State Highway and Transportation Officials (AASHTO). Guide for mechanistic-empirical design. 1st ed. Washington DC; 2004.

4. Ministerio de Transporte, Manual de Dise-o de Pavimentos Asfálticos para Vías con Bajos Volúmenes de Tránsito. Bogotá: Instituto Nacional de Vías; 2007.

5. Asphalt Institute, The Asphalt Handbook. Manual Series No. 4 (MS-4). Washington DC; 1989. pp. 1-607.

6. Reyes F. Dise-o racional de pavimentos. 1st ed. Bogotá: Escuela Colombiana de Ingeniería; 2003.

7. Montejo A. Ingeniería de pavimentos. 3rd ed. Bogotá: Universidad Católica de Colombia; 2006. 
8. Rondón H, Reyes F. Pavimentos-Materiales, Construcción y Dise-o, Bogotá DC, Colombia: ECOE Ediciones; 2015. pp. 1-650. PMid:26211959

9. Huang Y. Pavement Analisis and Design. 2nd ed. New Jersey: University of Kentucky; 2004.

10. Murgueitio A, Benavides C, Solano E. Estudio de los factores da-o de los vehículos que circulan por las carreteras colombianas. 11th Simposio Colombiano sobre Ingeniería de Pavimentos; Cartagena, Colombia. 1997. p. 33242.

11. American Association of State Highway and Transportation Officials (AASHTO), Guide for Design of Pavement Structures. 1st ed. Washington DC; 1993. p. 1-624.

12. Sánchez FY, Campagnoli S. Pavimentos asfálticos de carreteras: Guia Práctica Para Los Estudios Y Dise-os. 1st ed. Bogotá: Editorial Escuela Colombiana de Ingeniería; 2016. p. 1-518. 